\title{
Collaborative Monitoring of Production and Costs of Timber Harvest Operations in the Brazilian Amazon
}

\author{
Benno Pokorny $^{1}$, and Max Steinbrenner ${ }^{2}$
}

\begin{abstract}
Timber companies and policy makers in the Brazilian Amazon urgently need financial information on forest management. Results from a few experiments, case studies, and surveys have been groundbreaking, but are insufficient. A strategic partnership between timber companies and research organizations is needed to generate additional information. This paper presents a tool for monitoring production and costs of forest operations to facilitate such collaboration. The tool provides useful information for companies and, at the same time, generates reliable data for research. Selected results are presented on production, capacity, and costs to demonstrate the usefulness of the information that can be generated. These results are based on the first 2 years of implementation by a company in the State of Pará, Brazil. This pilot project confirmed that the tool is simple and relevant. Its successful implementation requires significant investment, and will be applicable only to companies interested in changing from conventional logging to reduced-impact logging, especially those seeking Forest Stewardship Council certification. Successful implementation of the tool will also depend on it generating readily understood and highly relevant results for the companies, and receiving extensive support during the first 2 years.
\end{abstract}

Key Words: Brazilian Amazon; costs; forest operations; monitoring; productivity; reduced-impact logging

\section{INTRODUCTION}

Although about 60 million ha of Amazonian forests have been converted to other land use since the first roads were opened in the 1970s, the Brazilian Amazon is still the world's largest remaining primary forest (Lele et al. 2000, Laurance et al. 2001). About 400 million ha of untouched forests have an estimated stock of more than 60 billion $\mathrm{m}^{3}$ of tropical hardwood. During the 1992 Earth Summit in Rio de Janeiro, sustainable forest management was identified as the preferred option to develop the economic potential of the region, while preserving the environmental value of the forests and addressing international concerns about deforestation (UNCED 1992).

Timber companies play a key role in utilizing Amazonian forests. Current annual production is estimated at about 28 million $\mathrm{m}^{3}$, generating a gross product of about one billion US dollars (Smeraldi and Veríssimo 1999, IBAMA 2002, Sobral et al.
2002). The sector is still dominated by family-run businesses. Nearly $75 \%$ of about 7600 mills are estimated to consume less than $4000 \mathrm{~m}^{3}$ of logs per year (IBAMA 2002, Lentini et al. 2003). Over $90 \%$ of Amazonian timber is derived from privately owned forests, and very few companies harvest their own forests. Privately negotiated logging concessions of 1 to 5 year's duration are common, and companies are continually searching for new harvesting areas to ensure their timber supply. Only a small proportion of the timber is logged in Forest Management Projects formally approved by the responsible government agency, the Brazilian Institute for Environmental and Renewable Natural Resources (IBAMA). In addition to illegal logging on private or unclaimed federal land, a significant proportion of the timber comes from deforestation activities from legally planned land conversion. It is often sourced from smallholders suffering severe economic problems. As a result, violence and social unrest characterize the situation along Amazonian logging frontiers (Cotton and Romine 1999, Lima 
et al. 2003).

Commercial timber harvesting in the Amazon has a very negative impact on future productivity and environmental values, resulting from a lack of law enforcement and infrastructure, deficiencies in education, corruption, and tenure conflicts (Embrapa 1996, Johns et al. 1996, Blate et al. 2001, Smith 2002). Unplanned use of skidders and bulldozers by unskilled operators causes enormous environmental damage (Barreto et al. 1998, Vidal et al. 2002). Most logging operations do not respect sensitive areas, such as riverbanks, and much timber is left behind in the forests due to lack of control and inadequate felling techniques. Fire and repeated logging further degrade the forests, and cattle ranchers and settlers often convert logged forests into agricultural land.

Reduced-impact logging (RIL) techniques have been developed to reduce the environmental impacts of timber harvesting, to avoid damage to future crop trees, and to improve the production efficiency of harvesting operations (Boltz et al. 2003). In contrast to conventional logging, RIL includes planning activities, such as area mapping, forest inventory, harvest block mapping, selecting and mapping harvest trees, planning infrastructure and skid trails, as well as applying specific felling techniques, and monitoring forest development after harvesting (Dykstra and Heinrich 1996, Sabogal et al. 2000, Wellhoefer 2002). However, only a few of the timber companies in the Brazilian Amazon, those seeking Forest Stewardship Council (FSC) certification, have adopted RIL practices. The timber industry is far from being a catalyst of sustainable development: indeed, socioeconomic and environmental problems in rural regions often become worse when industry is active on the Amazonian frontiers (Nepstad et al. 1999, 2000, Andersen et al. 2002).

Against this background, various policy recommendations have been suggested. One position supports sustainable forest management as the key to development of the Amazon region (Pearce et al. 2003, Boltz et al. 2003). Veríssimo et al. (2002) estimated that approximately 50 million ha are economically attractive for sustainable forest management, and the Brazilian government is planning to open up nearly 30 million ha of National Forests for timber harvest (MMA 2001). A second position suggests more attention be paid to subsistence and cultural values of forests by emphasizing small-scale forest management concepts (Lima et al. 2003, Nepstad et al. 2004). Another position questions whether private companies can be convinced to provide the longterm investments needed for sustainable forest management, given that commercial incremental growth rates of natural forests do not exceed $2 \mathrm{~m}^{3} /$ ha/yr (Rice et al. 2001).

This paper argues that, despite some excellent previous studies, existing information about sustainable forest management in the Amazon is not sufficient to adequately discuss these options. In particular, financial information is missing. Timber companies will only be persuaded to adopt sustainable forest management practices if it can be shown that RIL will generate financial profits. The managerial capabilities of the owners of most timber companies also need to be enhanced, as most have little or no training in management or forestry operations. We present here a tool for analyzing production and costs of forest operations. This tool, designed to be applied collaboratively by private timber companies and researchers, will initiate communication and learning for both parties, and will generate and distribute information about Amazonian forests needed by policy makers for decision making.

The paper briefly reviews different approaches applied to financial analysis of timber harvesting in the Amazon, and describes a tool for collaborative monitoring of production and costs. It demonstrates the tool's analytical potential through a series of results from its pilot application by a timber company in the eastern Amazon, and discusses to what extent the tool can be further applied on a broader scale.

\section{LITERATURE REVIEW: METHODS AND RESULTS OF FINANCIAL ANALYSIS IN THE BRAZILIAN AMAZON}

Studies of commercial timber logging in the Amazon began in the 1970s when the timber resources of the region became accessible to the timber centers in southern Brazil through the construction of the first Amazonian highways (Table 1). The Brazilian Organization for the Development of the Amazon (SUDAM), supported by the Food and Agricultural Organization (FAO) of the United Nations, conducted the first study of the technical and financial potential of forest 
management for the Amazon (SUDAM 1978). In the 1980s and 1990s, timber harvesting expanded greatly along old and new logging frontiers, but it was only at the end of the 1990s that the first financial analyses of environmentally sound forest management techniques became available for the region (Barreto et al. 1998, Holmes et al. 2000). Before these analyses, there were several reports on the timber sector and conventional logging (see Scholz 2001 for a comprehensive review), but the financial aspects of management were not studied. The few financial studies available give very different results (Table 2). For example, Costa Filho and Ferreira (1991) calculated costs of less than US\$8 per $\mathrm{m}^{3}$ for conventional logging in western Pará, and Muehlsiegl and Pokorny (1998) reported logging costs for the certified timber company, Mil Madeireiras, at nearly US $\$ 40$ per $\mathrm{m}^{3}$ due to extremely high administrative costs. Veríssimo et al. (1995) estimated that costs for highly selective mahogany harvesting in southern Pará were approximately US $\$ 150$ per $\mathrm{m}^{3}$. However, these three studies do not provide representative cost estimates for logging in the Amazon. The first study suffered from a lack of transparency in its methodology and does not allow recovery of the underlying cost types. The other two studies were very specific and cannot be generalized.

Other studies differ greatly in detail, although they show similar overall cost estimates averaging US\$17-37 per $\mathrm{m}^{3}$ (Table 2). Aside from the specifics of particular forests (i. e., species composition, forest structure, relief) and enterprises (i. e., staff, machines, work processes, enterprise organization), these differences are caused by differences in the methods of cost calculation and the methodological approach used for data collection. A closer inspection of these aspects reveals the limited compatibility of the studies, and explains the practical difficulties faced by companies and decision makers in using existing information.

\section{Cost Calculation}

All the studies consider costs for capital items (capital costs, depreciation, maintenance), labor, material, administration, and stumpage fees, but costs for risks and imputed salaries are ignored. Also, they look at the whole sequence of activities related to forest operations, including cutting, skidding, landing activities, and transportation. Costs for construction and maintenance of infrastructure (landings, and primary and secondary streets) are also included. Most studies also take into account costs of transportation from the Forest Management Unit to the sawmill along public roads. The RIL studies include additional costs for planning, e. g., area mapping, forest inventory, harvest block mapping, selecting and mapping harvest trees, and planning infrastructure and skid trails.

Differences occur mainly in the way the studies calculate costs. Some analyze only overall costs, but others define costs for selected activities. The studies also differ considerably in how they treat and distribute costs for administration and technical coordination. Most critically for comparison purposes, some studies use standard costs for labor and machinery, but others rely on enterprisespecific data. Finally, only some of the studies consider timber waste as a cost factor. Barreto et al. (1998) added a general surcharge of $25 \%$ to the costs of conventional logging for timber waste, whereas Holmes et al. (2000) used the potential value of the waste measured in the forest. The different treatment of timber waste by these researchers, rather than the different measurements of productivity in the field, resulted in greater differences in the overall result of their studies.

\section{Methodological Approaches}

The method used for data collection strongly influences the reliability and usefulness of the study results. Studies presented in Table 3 can be structured into (a) interview surveys, (b) in-depth case studies, and (c) experiments. Each approach has characteristically strong and weak aspects, resulting in a specific quality of the captured data.

Surveys: Mailed surveys are a popular and effective means of industry-researcher collaboration in developed countries (e. g., Dillmann 1978). The costs to both parties are relatively low, as surveys are designed to take as little time as possible. Options such as stamped, self-addressed envelopes lower obstacles and increase responses. Unfortunately, mail-in surveys are difficult for the majority of timber companies in the Amazon and the expected response rate is close to zero (C. Sabogal, N. Silva, and J. Zweede, pers. comm.) This methodology may 
Table 1. Characteristics of selected research on financial aspects of commercial timber harvest (RIL and CL) in the Brazilian Amazon

\begin{tabular}{|c|c|c|c|c|c|c|}
\hline Author & Year & Type of study & Sample size & $\begin{array}{l}\text { Type of } \\
\text { logging }\end{array}$ & Costs considered & Location \\
\hline SUDAM & 1978 & Experiment & unknown & CL & $\begin{array}{l}\text { Harvest and } \\
\text { transport }\end{array}$ & Curuá Una, PA \\
\hline $\begin{array}{l}\text { Costa Filho \& } \\
\text { Ferreira }\end{array}$ & 1991 & $\begin{array}{l}\text { Case study + time } \\
\text { study }\end{array}$ & 3 companies & $\mathrm{CL}$ & $\begin{array}{l}\text { Harvest and } \\
\text { transport }\end{array}$ & $\begin{array}{l}\text { Curuá Una, Jarí, } \\
\text { Flona Tapajós, } \\
\text { PA }\end{array}$ \\
\hline Veríssimo et al. & 1992 & $\begin{array}{l}\text { Survey (brief) } \\
\text { Survey (in-depth) }\end{array}$ & $\begin{array}{l}238 \text { companies } \\
33 \text { companies }\end{array}$ & $\mathrm{CL}$ & $\begin{array}{l}\text { Harvest and } \\
\text { transport }\end{array}$ & Paragominas, $\mathrm{PA}$ \\
\hline Veríssimo et al. & 1995 & $\begin{array}{l}\text { Survey } \\
\text { Field measurements }\end{array}$ & $\begin{array}{l}66 \text { companies } \\
1 \text { team, } 3 \text { x } 100 \text { ha }\end{array}$ & CL (mahogany) & Harvest & Tucumá, PA \\
\hline $\begin{array}{l}\text { FAO } \\
\text { Wellhoefer }\end{array}$ & $\begin{array}{l}1997 \\
2002\end{array}$ & Experiment & $\begin{array}{l}10 \text { ha RIL, } 10 \text { ha } \\
\text { CL }\end{array}$ & CL \& RIL & $\begin{array}{l}\text { Harvest and } \\
\text { transport }\end{array}$ & Itacoatiara, AM \\
\hline Barreto et al. & 1998 & Experiment & $\begin{array}{l}105 \text { ha RIL, } 75 \text { ha } \\
\text { CL }\end{array}$ & CL \& RIL & Harvest & Paragominas, PA \\
\hline Stone & $1998 \mathrm{a}$ & Survey & 40 companies & $\mathrm{CL}$ & $\begin{array}{l}\text { Harvest and } \\
\text { transport }\end{array}$ & Paragominas, PA \\
\hline $\begin{array}{l}\text { Muehlsiegl \& } \\
\text { Pokorny }\end{array}$ & 1999 & $\begin{array}{l}\text { Case study + time } \\
\text { study }\end{array}$ & $\begin{array}{l}1 \text { company } \sim 80 \\
\text { cycles }\end{array}$ & RIL & Harvest & Itacoatiara, AM \\
\hline Holmes et al. & 2000 & Experiment & $\begin{array}{l}100 \text { ha RIL, } 100 \text { ha } \\
\text { CL }\end{array}$ & CL \& RIL & Harvest & Paragominas, PA \\
\hline Pokorny \& Sousa & 2000 & $\begin{array}{l}\text { Case study + time } \\
\text { study }\end{array}$ & $\begin{array}{l}1 \text { company } \sim 70 \\
\text { cycles }\end{array}$ & $\mathrm{CL}$ & $\begin{array}{l}\text { Harvest and } \\
\text { transport }\end{array}$ & Tailândia, PA \\
\hline de Graaf et al. & 2002 & $\begin{array}{l}\text { Case study + time } \\
\text { study }\end{array}$ & 1 company & RIL & Harvest & Itacoatiara, AM \\
\hline
\end{tabular}

RIL $=$ Reduced Impact Logging; CL = Conventional Logging

$\mathrm{AM}=$ Amazonas State, $\mathrm{PA}=$ Pará State

be an important option in the future as communication networks improve, but currently creates biases in the responses that must be taken into account. Therefore, personal interviews are used to capture information. Regardless of survey details, the common denominator of this approach in the Brazilian Amazon is data collection from short, focused interviews, usually not exceeding 45 minutes. Numerous companies can be surveyed over a relatively short period and the data collected are the most broad and representative available. Because of their relative ease of application, surveys have been used in many of the research efforts in the timber industry (e. g., Veríssimo et al. 1992,
1995, Stone 1998a, 1998b, Nepstad et al. 1999). The advantage of easy and fast information access, however, is to some extent reduced by the unknown quality of the responses. This is especially true of financial information about commercial forest operations, as Amazonian timber companies characteristically are run by self-made managers who have little business management training, deficient bookkeeping practices, and restricted financial control of forest operations (Arima and Veríssimo 2002, Pearce et al. 2003). Companies tend to focus their interest on mill processing and sales, not on forest operations. 
Table 2. Harvest and transport costs $\left(\mathrm{US} \$ / \mathrm{m}^{3}\right)$ in selected studies.

\begin{tabular}{|c|c|c|c|c|c|c|c|c|c|c|c|c|}
\hline Study & Year & Type of logging & $\begin{array}{l}\text { Stumpage } \\
\text { Fee }\end{array}$ & $\begin{array}{l}\text { Invent- } \\
\text { ory }\end{array}$ & $\begin{array}{l}\text { Infra- } \\
\text { str. }\end{array}$ & $\begin{array}{l}\text { Fell- } \\
\text { ing }\end{array}$ & $\begin{array}{l}\text { Skidd- } \\
\text { ing }\end{array}$ & $\begin{array}{l}\text { Land- } \\
\text { ing }\end{array}$ & $\begin{array}{l}\text { Ot- } \\
\text { her }\end{array}$ & $\begin{array}{l}\text { Subto- } \\
\text { tal } \\
\text { Logg- } \\
\text { ing }\end{array}$ & $\begin{array}{l}\text { Trans- } \\
\text { port }\end{array}$ & TOTAL \\
\hline & & CL Tapajós & n.r. & 0.65 & 0.42 & 0.46 & 1.48 & n.r. & 1.30 & 4.31 & 3.37 & 7.68 \\
\hline \multirow{2}{*}{$\begin{array}{l}\text { Costa Filho \& } \\
\text { Ferreira }\end{array}$} & 1991 & CL Jarí & n.r. & 0.65 & 2.94 & 0.41 & 1.96 & n.r. & 2.50 & 8.46 & 3.89 & 12.35 \\
\hline & & CL Curuá Una & n.r. & 0.65 & 2.09 & 0.56 & 1.77 & n.r. & 2.18 & 7.25 & 2.86 & 10.11 \\
\hline Veríssimo et al. & 1992 & CL small scale & 1.90 & n.r. ${ }^{a}$ & & & & & & 11.11 & 8.42 & 21.43 \\
\hline \multirow[t]{2}{*}{ Veríssimo et. al. } & 1995 & Mahogany & 40.00 & 4.60 & & & 23.80 & & 7.60 & 36.00 & 75.90 & 151.90 \\
\hline & & CL small scale & 5.00 & n.r. ${ }^{a}$ & & & & & & 12.60 & 20.09 & 37.69 \\
\hline \multirow[t]{3}{*}{ Stone ${ }^{a}$} & 1998 & CL large scale & 5.00 & n.r. ${ }^{a}$ & & & & & & 10.34 & 18.09 & 33.43 \\
\hline & & CL small for ' 92 & 2.21 & n.r. ${ }^{a}$ & & & & & & 13.93 & 13.39 & 29.53 \\
\hline & & RIL & 5.00 & 1.87 & 0.28 & 0.25 & 1.31 & 2.59 & 4.18 & 10.48 & 11.00 & 26.48 \\
\hline Baretto et al. & 1998 & $\mathrm{CL}$ & 5.00 & 0.00 & 0.40 & 0.40 & 1.37 & 2.53 & 4.18 & 8.88 & 11.00 & 24.88 \\
\hline $\begin{array}{l}\text { Muehlsiegl \& } \\
\text { Pokorny }\end{array}$ & 1998 & RIL & 5.00 & 4.04 & 3.03 & 2.72 & 3.78 & 2.83 & $\begin{array}{l}15 .- \\
25\end{array}$ & 36.65 & 3.22 & 39.87 \\
\hline \multirow[t]{2}{*}{$\begin{array}{l}\text { Pokorny \& } \\
\text { Sousa }\end{array}$} & 2000 & $\mathrm{CL}$ & 4.95 & n.r. & & & & & & 10.69 & 6.27 & 21.91 \\
\hline & & RIL & 7.61 & 1.18 & 0.32 & 0.62 & 1.51 & 1.28 & 1.07 & 5.98 & 10.00 & 23.59 \\
\hline Holmes et al. & 2000 & $\mathrm{CL}$ & 9.09 & 0.00 & 0.57 & 0.65 & 1.99 & 2.01 & 0.97 & 6.19 & 10.00 & 25.28 \\
\hline Wellhoefer & 2002 & RIL & n.r. & 2.50 & n.r. & 5.00 & 12.00 & n.r. & n.r. & 19.50 & $4.50^{\mathrm{c}}$ & 24.00 \\
\hline $\begin{array}{l}\text { Pokorny \& } \\
\text { Steinbrenner }\end{array}$ & 2004 & $\begin{array}{l}\text { RIL Implement- } \\
\text { ation }\end{array}$ & 4.81 & 0.84 & 0.69 & 0.97 & 2.75 & 2.06 & 0.68 & 7.37 & 4.23 & 17.28 \\
\hline
\end{tabular}

RIL $=$ Reduced Impact Logging; CL = Conventional Logging.

n.r. $=$ not reported

${ }^{a}$ Both Veríssimo (1992) and Stone (1998a, b) calculate costs per item rather than by activity: i. e. salaries and benefits, fuel, maintenance, depreciation, capital costs, forest tax, and estimated management costs.

$\mathrm{b}$ The total costs correspond to value in US\$ given by the authors for the period of each study. They have not been adjusted to the present because of the difficulty of addressing the effects caused by the change of currency (Cruzeiro to Real, 1994) and the devaluation of the Real against the US dollar since then. It is quite probable that the effect of inflation is partly offset by the effect of devaluation. That said, it is important that the relative costs be examined with the caveat that the values are not fully comparable.

${ }^{\mathrm{c}}$ For an estimated distance of $30 \mathrm{~km}$ 
Table 3. Advantages and disadvantages of previous research methodologies

\begin{tabular}{|c|c|c|}
\hline Methodology & Advantages & Disadvantages \\
\hline Survey & $\begin{array}{l}\text { Statistically significant; broad; expert-based; timely; } \\
\text { cost effective; huge sample size possible }\end{array}$ & $\begin{array}{l}\text { Dependence on secondary information, thus data } \\
\text { of unknown quality }\end{array}$ \\
\hline Case Study & $\begin{array}{l}\text { Close contact with personnel; broader questions; and } \\
\text { in-depth questions possible }\end{array}$ & $\begin{array}{l}\text { Only applicable to few cases; expensive; } \\
\text { dependence on secondary information and } \\
\text { knowledge by personnel; includes many } \\
\text { assumptions }\end{array}$ \\
\hline Experiment & $\begin{array}{l}\text { Control over data quality; allows for the testing of a } \\
\text { variety of alternate scenarios and ideas }\end{array}$ & $\begin{array}{l}\text { Only applicable on a limited scale; expensive; } \\
\text { upward bias through extrapolation; specific; } \\
\text { individual; and non-comparable assumptions } \\
\text { between experiments }\end{array}$ \\
\hline
\end{tabular}

Case studies: Case studies are an important option in production research (e. g., Yin 2002). Through direct access to the documents and the opportunity to ask specific questions of company staff, including managers, information from case studies is significantly more reliable than that captured by surveys. Nevertheless, case studies also suffer from reliance on company-based information of unknown quality. Much more time is needed, making the process more expensive, and because only a limited number of companies can be considered, the applicability of the findings is restricted.

Experiments: In contrast to surveys and case studies, the researcher has greater control over the data quality in experiments, but experiments also have drawbacks. They are expensive and specific, and can therefore only be applied on a restricted scale over a limited time. This has various implications. Factors present under operational working conditions, such as accidents, illness, unfavorable weather, problems with machinery, and bureaucratic transaction costs, are widely ignored. Experiments are normally well organized and workers tend to work more consistently under intensive observation. The harvested volume can vary widely in different areas due to heterogeneity of tropical forests. For example, the average yields measured by Barreto et al. (1998) and Holmes et al. (2000) in their 100-ha study areas in Paragominas district varied from 25.4 $\mathrm{m}^{3}$ to $38.6 \mathrm{~m}^{3}$ per ha, which impacted significantly on their financial results. Another obstacle for the replication of experimental results is the difficulty in obtaining an accurate estimate of forest areas not suitable for harvesting because of slopes, rivers, or species availability. These exclusion areas vary greatly, depending on forest quality, markets, and commitment of companies to legislation. Indirect costs resulting from social services, coordination of forest operations, and maintenance of equipment depend on a variety of very specific company parameters such as organization, logistics, and harvesting techniques. It is nearly impossible to adequately consider these specific factors in experiments, which is why the cited studies differ considerably in this aspect. Generally, experiments run the danger of introducing a bias in methodological design, data analysis, and interpretation of results. These difficulties imply that results must be extrapolated with care and that there is a risk that linear extrapolation may underestimate actual costs. Sensitivity analysis or the consideration of scenarios on productivity and costs are possible ways to address this problem.

Notwithstanding efforts to date, there continues to be an urgent need for reliable data on forest management in the Amazon. Specifics of methodological design and underlying data make it difficult for relevant actors to base their decisions on information provided by existing studies. Company managers need information on their own operations in accordance with their local conditions and taking into account specific depreciation periods, levels of salaries, stumpage fees, and annual interest rates. Banks depend on data reflecting the diverse conditions of forest companies as a basis for applying their cost calculation models. Data on forest operations in the Amazon are also 
needed to feed decision-support tools such as RILSIM (www.blueoxforestry.com) or to design cost models with regional validity for policy makers. To satisfy these demands for reliable data, long-term studies are needed to provide information on the diversity of technical, socioeconomic, and environmental conditions of timber companies in the Amazon.

\section{COLLABORATIVE MONITORING}

Following the principles of the Integrated Natural Resource Management approach as outlined by Lal et al. (2001) and Sayer and Campbell (2001, 2003), active involvement of timber companies in research is fundamental to ensure relevance and local ownership of the research process, and to increase acceptance of research outcomes. In fact, most studies of commercial forest management, independent of the methodological approach chosen, have collaborated with timber companies in an attempt to generate realistic and relevant information. In many cases, researchers became technical supervisors for the timber company being observed. There are many long-term partnerships: for example, in Sabah, Malaysia; Labanan and Bulungan, Indonesia; the BOLFOR project, Bolivia (see Enters et al. 2002); as well as the International Tropical Timber Organization (ITTO) project related to this study. These partnerships assist the companies in implementing more sustainable forest management regimes, often with the intention of establishing demonstration sites and generating manuals, scientific publications, and computer tools related to the promotion of sustainable forest management (see, for example, the FAO ( http://www.fao.org/forestry), ITTO (

http://www.itto.or.jp/), and Center for International Forestry Research (CIFOR) (

http://www.cifor.cgiar.org/) websites.

The uptake of available information and tools by timber companies outside these "research" partnerships is quite limited for various reasons. Many timber companies are simply not interested in innovations and prefer to continue with their welltried and lucrative harvesting concepts (Scholz 2001), or they do not have the capacity to apply scientific results to their own situations, to understand publications written in scientific jargon, or to use existing computer tools (Barreto and Arima 2002). Also, the partnerships have often been only short term and focused on environmental issues that are not a priority for companies.

It is important to have collaboration between timber companies, as owners and users of financial information on forest management, and researchers with the capacity to interpret and analyze the information. This collaboration should have a longterm perspective and aim to initiate learning processes for both parties; for researchers to have a better understanding of the realities of commercial logging in the Amazon, and for timber enterprises to enhance managerial capabilities needed for the innovative management that is fundamental for implementing sustainable forest management. Simple tools are needed to support such strategic partnerships.

Since 1998, there has been scientific cooperation between the Brazilian Research Organization for Agriculture (EMBRAPA) and CIFOR in collaboration with the Brazilian subsidiary of the Tropical Forest Foundation (FFT) and the Brazilian timber company Juruá Florestal Ltda (referred to as Juruá). This partnership developed a tool to systematically monitor the production and costs of forest management operations. "Collaborative monitoring" is the term used to describe a long-term association where companies apply a simple tool to systematically collect data needed for financial analysis, and researchers provide assistance in data interpretation and receive reliable data for their research. It is expected that examination of financial aspects of their own forest management operations will increase the sensitivity and interest of forest companies in innovations to increase operational efficiency and reduce environmental damage. For the researchers, this collaboration will facilitate a better understanding of timber companies as a basis for improved recommendations and research.

\section{Guiding Principles}

Simplicity, continuity, and precision are the three guiding principles to ensure practical relevance and adequate data quality.

Simplicity: Illiteracy is common in the Amazon region, and to circumvent this obstacle numerical codes were used to report workers' names, machines, and activities. Numerical codes also facilitate the data entry and reduce input error. Only team leaders, usually those most literate, had to complete data forms. Only basic information was 
sought, such as daily production, team composition, and working time. However, complete input accounting was required for each machine.

Continuity: Forest operations suffer from a wide variety of disturbances and irregularities, such as rain, broken machines, or waiting time for equipment; thus, point sample information may vary significantly from reality. This is especially true for badly organized forest operations with poorly maintained equipment, and in extreme environmental conditions prevalent in the Amazon. A continuous daily documentation of the working process over the whole year was used to capture this irregularity.

Precision: Amazonian timber companies, due to a lack of organization and qualification, may overlook important factors in their cost accounting, such as capital costs, temporary workers, employees related to general services, costs related to social services, and small machinery. Cost monitoring had to guarantee a complete consideration of all relevant factors based on systematic accounting.

\section{Data Collection}

The above principles have been put into practice in a monitoring process involving three system components: reports, database, and administration routines. Production of different forest operations, and relevant forest expenses and consumption were systematically documented in five reports:

1. daily field reports showing the daily production, location of work, team composition, and working time for each working team;

2. overview sheets providing a monthly overview of the presence of forest workers and supporting staff;

3. machine reports documenting maintenance and consumption, including oil and diesel.

4. machine overview sheets giving a monthly overview of application for heavy machines, chainsaws, and vehicles; and

5. expenditure sheets of chronologically occurring expenses not directly related to specific workers or machines, but with relevance to the forest sector.

All data were transferred to a database, which enabled analysis of monthly and average production and costs for different activities, teams, machines, and projects. This process required continuous updating of data, such as lists of forest workers and their monthly salaries; lists of machines, their prices, and depreciation periods; lists of monitored activities and measurement units; and lists of parts and material and their prices. Beyond this, constant, company-specific parameters were defined, such as duration of the harvesting period and the firm's interest rate. The data bank designed with the Microsoft Office software ACCESS was transformed into a professional freehand software.

Clearly defined administration procedures for data collection, processing, and control are fundamental for effective monitoring. The complexity of the tasks requires an information manager to support and supervise the whole monitoring process.

The following process elements have been identified (Fig. 1):

1. At the end of each day, each production team leader must fill in the field reports. Those responsible for the machine operators update the machine reports regarding consumption of diesel, lubricants, and spares.

2. Reports are collected and checked by the information manager, who must also complete the overview sheets for workers and machinery. Any uncertainties or questions should immediately be addressed.

3. Field reports, machine reports, and overview sheets are sent to the administration office on a predetermined, regular schedule.

4. Office personnel must check report quality, and also document on the expenditure sheets all expenses related to forests. Machinerelated expenditures should be documented separately for each machine.

5. All data should immediately be transferred to the database. Automatic checks in the software identify inconsistencies, which are 
Fig. 1. Schematic of collaborative monitoring process.

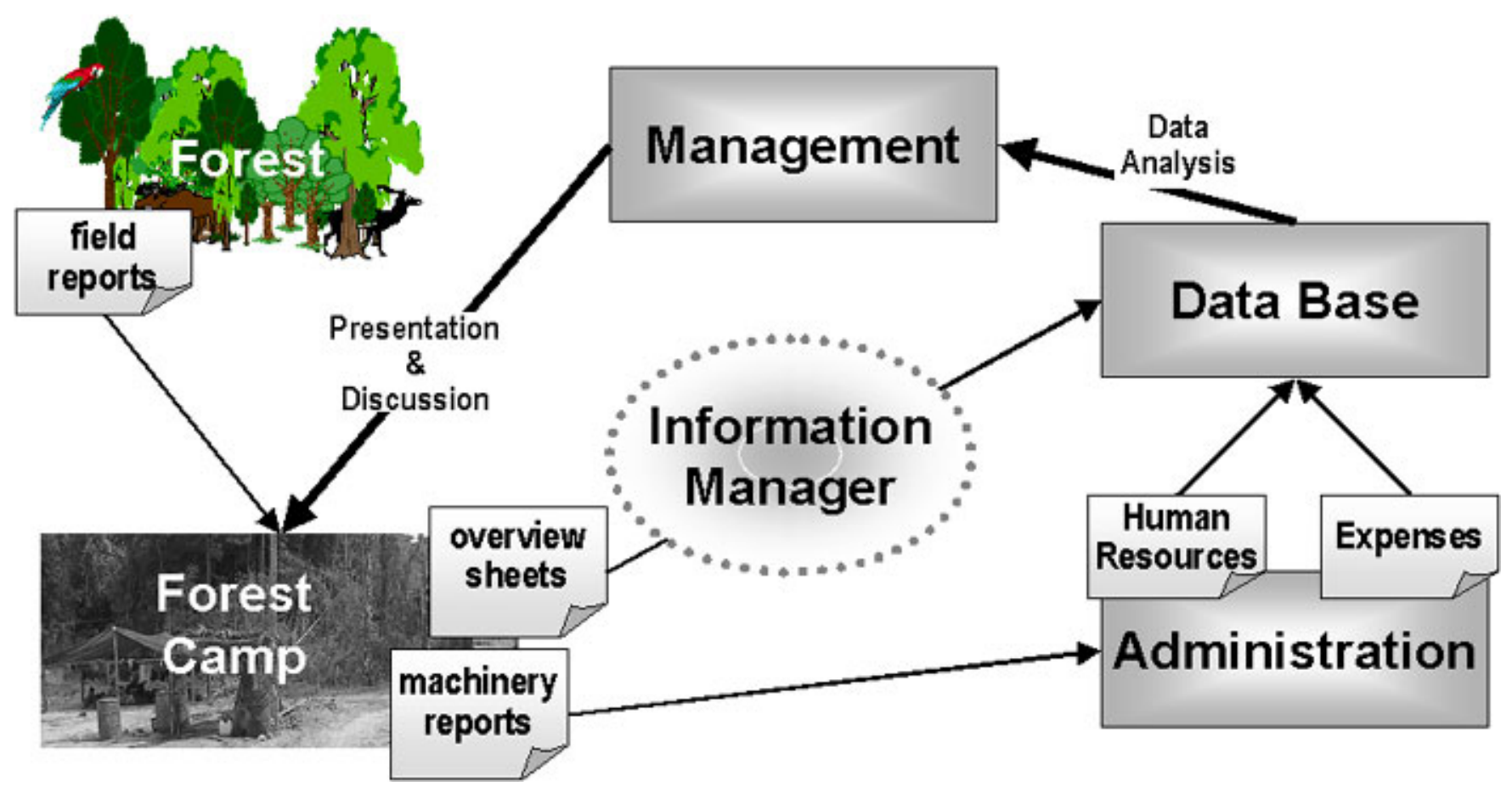

listed, and must be reported immediately to the information manager. Due to a high turnover rate, data on employees must be updated continually. The list of machinery must also be updated.

6. The software enables generation of standardized results on monthly production and costs, which should be reported to management. The cost calculation considers the following elements: human resources, capital costs, equipment, material, depreciation, and general expenses related to the forest sector. The company defines interest rates and depreciation periods. Expenditures outside the harvesting period are totaled and distributed throughout the harvesting period.

7. Managers should review the results and have the opportunity to discuss them with the information manager and forest workers. This feedback ensures interest in the monitoring process, and provides a learning experience.
Data presented in this paper span the period from August 2000 to July 2002, during which there was a transition from conventional logging to RIL. Daily field reports were completed for each operation, in particular for: cutting line establishment, inventory, infrastructure planning, road construction, landing construction, tree marking, felling, skid trail planning, skidding, loading, and permanent sample plot establishment. All calculated costs were based on information collected in conjunction with the company. Inconsistent, false, or missing data, a common occurrence during preliminary application of tools under development, were accounted for by using averages or plausible estimates.

\section{Research Site}

Juruá's head office is located near Belém, the state capital of Pará. The company has two sawmills. The Forest Management Unit in this study is located 50 $\mathrm{km}$ west of the town Tailândia and is approximately 
Fig. 2. The location of the Forest Management Unit "Santa Marta" managed by the Brazilian timber company Juruá Florestal Ltda.

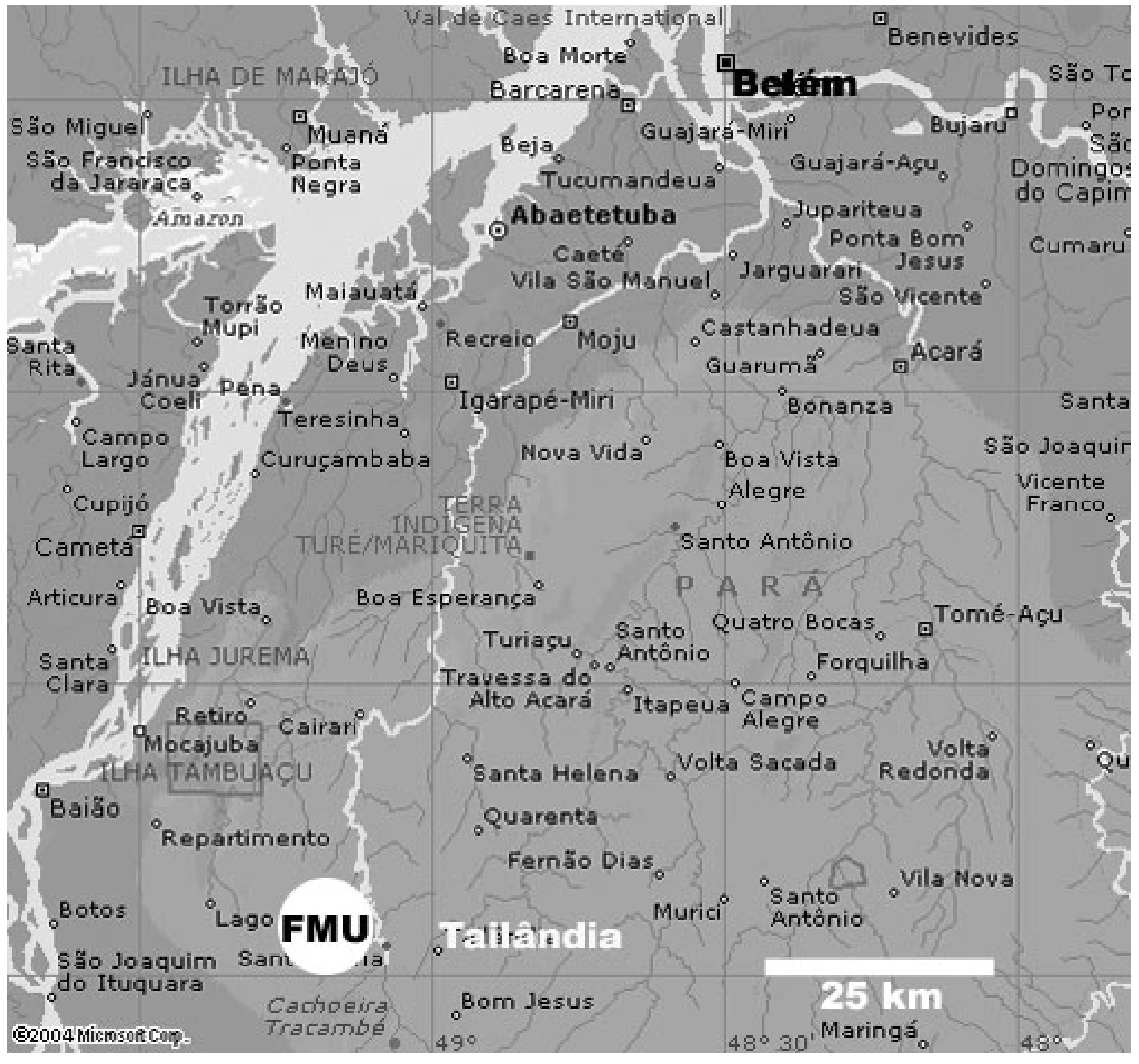

12000 ha in extent (Fig. 2). Its topography is flat to moderately undulating, and crossed by many small rivers. The soils are red and yellow Latosols. Mean annual rainfall is about $2000 \mathrm{~mm}$, and mean annual temperature is $26-27^{\circ} \mathrm{C}$ (Köppen and Geiger 1954). The characteristic vegetation type in the area is
Floresta Tropical Ombrófila upland forest. Harvesting operations are restricted to the drier season (June to November) because of heavy rain from December to May. The Forest Management Unit was divided in six annual coupes, each 2000 ha. The company applied conventional logging 
techniques, characterized by repetitive and unplanned extraction of a few commercial tree species until 2000 when, under the auspices of the ITTO project, it started to manage 400 ha under RIL guidelines (Sabogal et al. 2000). The quality of harvesting operations improved considerably, and in 2001, Juruá was awarded FSC certification for its entire operation.

During the harvest period, up to 50 people worked in the Forest Management Unit. The approximate harvest volume was $40000 \mathrm{~m}^{3}$ per year. The company deployed the following machinery: three CAT 518 skidders (all 1994 models), two loaders (CAT 930, CAT 935; both 1995 models), one D6D bulldozer (1993 model), one Volkswagen 7100 Truck (1994 model) for personal transport, and several chainsaws. All heavy machinery was bought in 1999 for about US\$100 000/machine. Most timber companies in the Amazon depreciate heavy machinery only for tax declarations, and not for cost calculation. Due to lack of capital, they usually purchase second-hand machines past their depreciation period, as defined by the manufacturer. According to the value of these capital items to the companies, this study included machinery depreciation for the second-hand machinery based on purchase date and value and a depreciation period of 6.5 years from date of acquisition, which corresponds to the expected lifespan stated by the company manager. Capital costs have been calculated at an interest rate of $9.7 \%$, set by the Central Bank of Brazil (Banco Central) in accordance with the norms of the National Monetary Committee (Conselho Monetário Nacional) for the relevant period.

\section{RESULTS}

Although there have been various adaptations to the monitoring tool since its inception in 1999, the 2 years of data permit an in-depth analysis of the harvesting operations, including the effects of RIL implementation and FSC certification. This section presents selected results to demonstrate the utility of the information for timber companies, which is a precondition to promote interest and stimulate learning. These examples show how the monitoring provides companies with information needed to plan finances and operations, to detect training needs, to evaluate effects of innovations, and to decide on investment in capital items. To indicate the potential for scientific analysis, the examples chosen interpret the financial impact of RIL for the company.

\section{Production}

Average daily productivity results for the principal harvesting activities are shown in Table 4. Inspection of minimum and maximum levels indicates the overall variability in daily production. This variability can be attributed to changing working conditions, techniques, and team composition over the observation period. The frequency of observations over 2 years makes it feasible to estimate realistic means for daily production of all monitored activities. This is fundamental for financial and operational planning. For example, Fig. 3 shows the development of the daily mean productivity of three felling teams for the harvest periods in years 2000 and 2001. At the beginning of 2000, the teams were trained to use directional felling techniques aiming at greater safety, less damage to future crop trees, and less timber wastage from felled trees. The switch to directional felling required working with maps, increased attention to safety, and application of specific felling techniques. These changes reduced daily felling rates significantly (by more than eight trees). The teams needed more than 2 months' practice to consolidate their productivity. This positive trend, interrupted by the start of the wet season in December, continued in 2001, although productivity rates never reached the level of conventional felling. The example reveals the importance of monitoring the effects of new technologies, of identifying possible difficulties in a timely manner, and of devising appropriate measurements. It also shows the need to realistically estimate productivity and costs as a prerequisite for planning operations.

Figure 3 also shows a regular productivity pattern for forest operations in the Amazon, characterized by an increase to the midpoint of the harvest season, followed by a decrease as difficult conditions take their toll on workers and machines. Harvest operations are further hindered, and finally stopped, by the onset of the rainy season. Monitoring this trend helps determine when a specific activity should be stopped for financial reasons.

Productivity is sensitive to changing working 
Table 4. Average monthly production in the principal harvesting activities for the period August $2000-$ December 2001

\begin{tabular}{|c|c|c|c|c|c|c|}
\hline Activity & Unit & Mean $^{\mathrm{a}}$ & Min & $\operatorname{Max}$ & $\mathrm{SE} \%$ & $\mathrm{n}$ \\
\hline Establishing cutting lines & meters & 1863 & 100 & 5428 & 40 & 579 \\
\hline Inventory' & trees & 147 & 10 & 331 & 42 & 334 \\
\hline Constructing roads (without planning) & meters & 498 & 110 & 1000 & 60 & 240 \\
\hline Constructing landings (without planning) & landings & 3 & 1 & 8 & 62 & 110 \\
\hline Marking trees & trees & 51 & 12 & 117 & 36 & 56 \\
\hline Felling & trees & 16 & 1 & 50 & 39 & 1039 \\
\hline Planning skid trails & trees & 43 & 3 & 148 & 52 & 285 \\
\hline Skidding & $\operatorname{logs}$ & 40 & 2 & 104 & 47 & 585 \\
\hline Loading & $\mathrm{m}^{3}$ Francon $^{\mathrm{b}}$ & 196 & 4 & 441 & 44 & 282 \\
\hline Establishing Permanent Sample Plots & plot & 1 & 0.1 & 2 & 38 & 91 \\
\hline
\end{tabular}

${ }^{a}$ Rounded to nearest whole figure

${ }^{b}$ A historical anomaly of the Pará timber industry is the use of $\mathrm{m}^{3}$ Francon to express the log-volume, calculated by the formula length $\mathrm{x}$ diameter $\mathrm{x}$ diameter $\mathrm{x} 4$. In addition, diameter and lengths are reduced according to species-specific indices established by IBAMA or the regional market, the real-geometric - volume is therefore underestimated; on average $1 \mathrm{~m}^{3}$ Francon corresponds to about $0.75 \mathrm{~m}^{3}$.

conditions, such as weather, stocking density, croptree diameter, quality of maps, and equipment. There are also significant differences between teams, so by examining the teams individually, further benefits can be obtained. There was great variation in the daily productivity of the teams (Fig. 4). Team 3 felled nearly two trees per day more than the other teams. This suggests an opportunity to improve the performance of the other teams by internal training or other measures.

\section{Unused Capacity}

Timber company managers in the Amazon perceive machines as an important cost factor, but seldom have control of their performance and effects on costs. Analysis of the proportion of lost workdays for three skidders during two harvest periods revealed that, on average, only $63 \%$ of machine capacity was used (Table 5). About $12 \%$ of potential working time was lost due to operator absenteeism and general breaks on Sundays, while another $15 \%$ loss resulted from mechanical failures. A comparison with the results of skidding trails in the USA, where a skidder worked at peak productivity more than $90 \%$ of the workday (McDonald and Rummer 2001) indicates the extent of lost capacity. Most surprising in our study was the high proportion of time spent in support work, which was mainly towing trucks through impassable stretches of roads. This non-skidding activity is primarily at the beginning and end of the harvest season when rain affects the movement of loaded trucks. The loss of a third of the existing skidding capacity had serious repercussions on costs. This increased costs per harvested cubic meter of timber by more than $10 \%$, using estimated average costs for capital, depreciation, and the working team of about US\$150 per day. Quantifying in detail the effects on costs of technical problems and inappropriate use of machines could stimulate companies to review their investment in adequate maintenance, new machinery, and operator training. 
Fig. 3. Daily production and overall means of three felling teams during the harvest periods 2000 and 2001 , affected by the implementation of directional felling as part of RIL in September 2000.

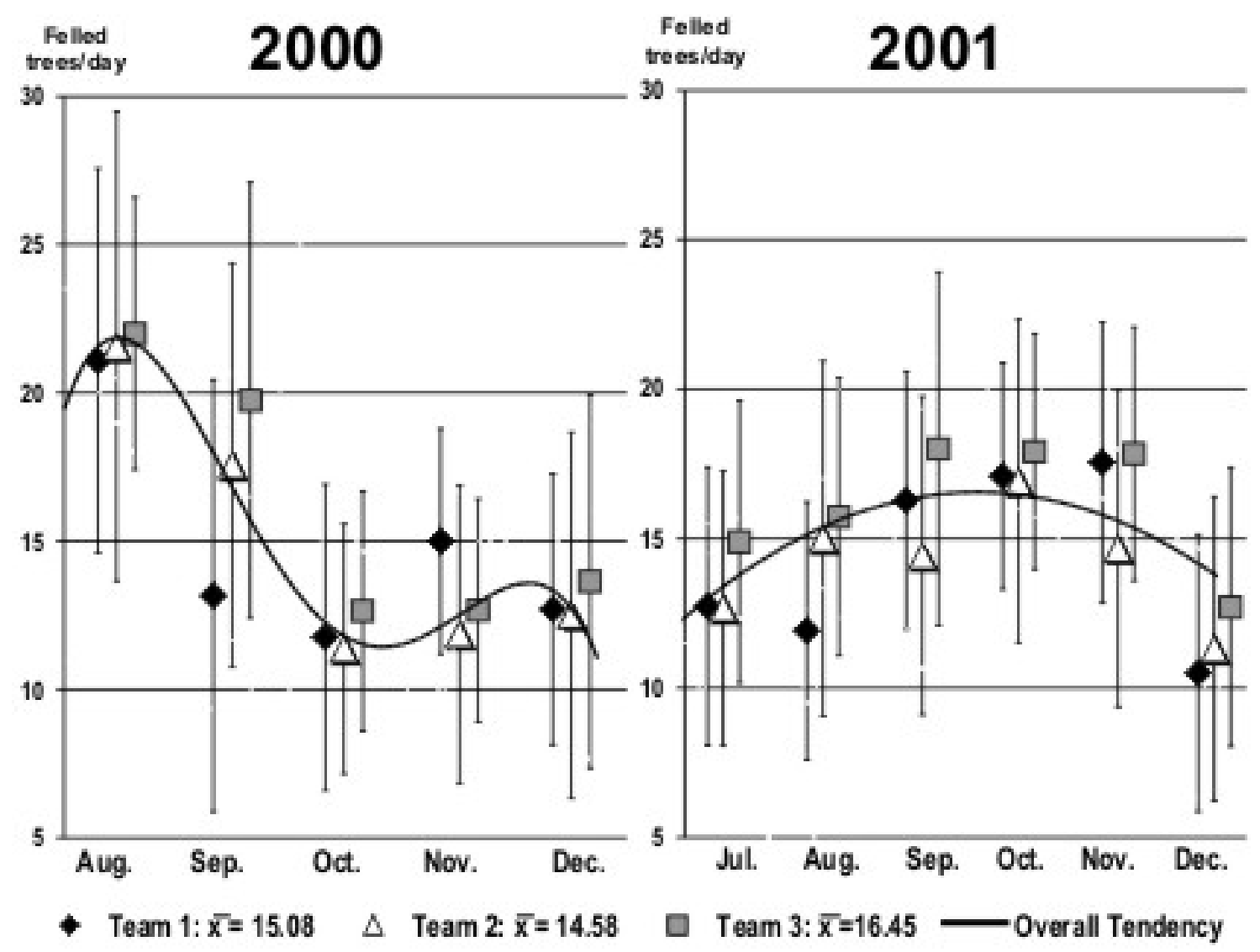

\section{Costs}

During the years 2000 and 2001, Juruá harvested nearly 16500 trees, representing a volume of about $80000 \mathrm{~m}^{3}$ on 5500 ha of primary forests. This corresponds to a logging intensity of $14.5 \mathrm{~m}^{3} /$ ha and an average volume of about $5 \mathrm{~m}^{3} /$ tree. The fact that Barreto et al. (1998) and Holmes et al. (2000) measured double this harvest volume per hectare in their experiments confirms the methodological difficulty of extrapolating data from small-scale experiments to the larger areas of Forest Management Units. The net harvestable area was less than $70 \%$ in the Forest Management Unit we studied.

Using these factors and the information provided by the daily reports for each logging activity, the costs per cubic meter were calculated for each of the principal forest activities. We used the historical monthly average Interbank Exchange Rates to transform the Brazilian currency (Real) into US dollars (http://www.oanda.com/converter).

Skidding and landing activities accounted for more than $60 \%$ of all operational costs (Table 6). Another $20 \%$ came from infrastructure construction and felling, activities requiring a significant use of machinery. The contribution of labor-intensive activities, however, was relatively small. Nearly $60 \%$ of total costs was directly related to machines, including over $7 \%$ by chainsaws. In general, due to the age of the machines, the proportion of variable costs for maintenance and consumption were higher 
Fig. 4. Daily productivity of three felling teams during the harvest periods 2000 and 2001, by productivity classes.

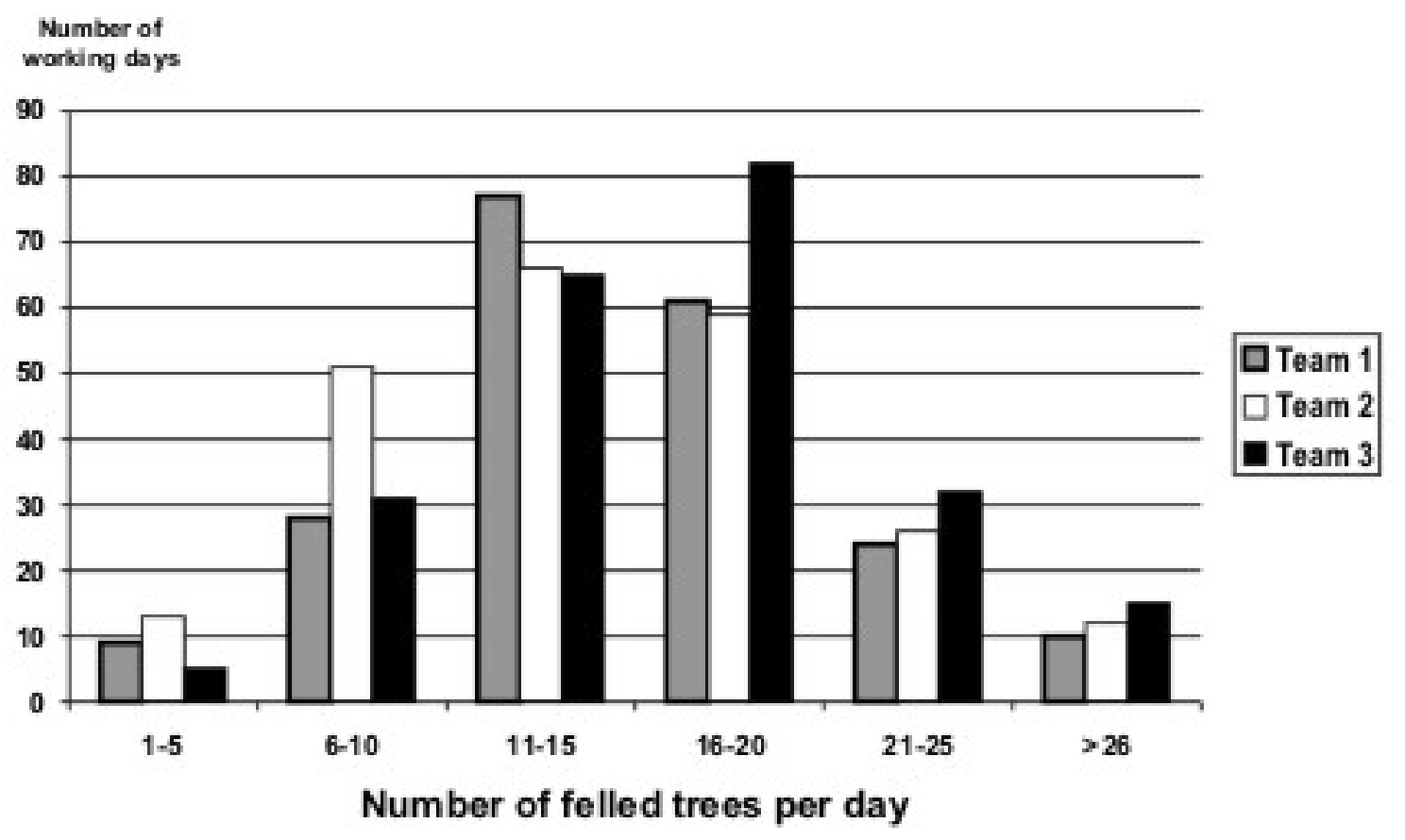

Table 5. Proportion of lost workdays for three skidding teams for the period August 2000-December 2001

\begin{tabular}{|c|c|c|c|c|c|c|c|}
\hline Machine & $\begin{array}{l}\text { Potential wo- } \\
\text { rking days }^{\mathrm{a}}\end{array}$ & $\begin{array}{l}\text { Misc. } \\
\text { stoppage }^{b}\end{array}$ & Defect & $\begin{array}{l}\text { Subtotal wor- } \\
\text { king days }\end{array}$ & $\begin{array}{l}\text { Active skidding } \\
\text { days }\end{array}$ & $\begin{array}{l}\text { Support } \\
\text { work }^{\mathrm{c}}\end{array}$ & $\begin{array}{l}\text { Percentage of } \\
\text { days skidding }\end{array}$ \\
\hline Skidder 1 & 325 & 46 & 20 & $259(80 \%)$ & 231 & 28 & $71 \%$ \\
\hline Skidder 2 & 327 & 25 & 71 & $231(71 \%)$ & 184 & 47 & $56 \%$ \\
\hline Skidder 3 & 285 & 44 & 36 & $205(72 \%)$ & 179 & 26 & $63 \%$ \\
\hline Total & 937 & 115 & 127 & $695(74 \%)$ & 594 & 101 & $63 \%$ \\
\hline
\end{tabular}

${ }^{a}$ Days when the skidder was available in the Forest Management Unit during the harvest period

b Miscellaneous delays caused by operator absenteeism, working breaks during the weekends, or rainy days (only counted when skidder was not stopped because of defects)

${ }^{c}$ Support work consists primarily of extracting trucks that are stuck on poor roads during the rainy days 
Table 6. Average harvesting cost per $\mathrm{m}^{3}$ of round wood and the participation of different cost types (without transport and fees)

\begin{tabular}{|c|c|c|c|c|c|c|c|}
\hline \multirow[b]{3}{*}{ Reported Activities } & \multirow{2}{*}{\multicolumn{2}{|c|}{ Costs per $\mathrm{m}^{3}$}} & \multicolumn{5}{|c|}{ Proportion of costs $(\%)$} \\
\hline & & & \multicolumn{2}{|c|}{ Labor } & \multicolumn{2}{|c|}{ Machines } & \multirow[b]{2}{*}{ Misc. } \\
\hline & US\$ & $\%$ & Field teams & Support & Fixed & Variable & \\
\hline Cutting lines & 0.49 & 6.6 & 37 & 33 & 0 & 0 & 30 \\
\hline Inventory, vine cutting & 0.35 & 4.7 & 51 & 28 & 0 & 0 & 21 \\
\hline Tree marking & 0.03 & 0.5 & 50 & 23 & 0 & 0 & 27 \\
\hline Felling & 0.93 & 12.6 & 23 & 15 & 5 & 25 & 32 \\
\hline Infrastructure planning & 0.05 & 0.7 & 30 & 26 & 2 & 3 & 38 \\
\hline Infrastructure construction & 0.58 & 7.8 & 8 & 4 & 32 & 47 & 9 \\
\hline Skid trail planning & 0.29 & 3.9 & 33 & 26 & 0 & 0 & 40 \\
\hline Skidding & 2.46 & 33.2 & 8 & 5 & 28 & 49 & 10 \\
\hline Landing activities & 2.06 & 27.8 & 12 & 6 & 27 & 42 & 13 \\
\hline Infrastructure maintenance & 0.06 & 0.8 & 9 & 3 & 56 & 20 & 13 \\
\hline Monitoring (PSP/ damages/waste) & 0.05 & 0.8 & 43 & 24 & 1 & 2 & 30 \\
\hline \multirow[t]{2}{*}{ Others (Research etc.) } & 0.02 & 0.4 & 36 & 23 & 0 & 0 & 41 \\
\hline & & & 17 & 10 & 20 & 36 & 17 \\
\hline TOTAL & 7.37 & $100^{\mathrm{a}}$ & & (27) & $(56$ & & (17) \\
\hline
\end{tabular}

${ }^{\text {a }}$ May not add up due to rounding

than the costs for capital and depreciation. About $17 \%$ of overall costs were related to miscellaneous costs, such as administration, food, supporting vehicles, and small equipment. Only a quarter of the overall cost was attributed to labor, including coordination and support staff, such as forest technicians, a driver, and a cook. These results should help convince managers of the importance of adequate training for their staff, especially machine operators, and retention of trained staff by paying appropriate salaries.

The trend of skidding costs per log during the harvest periods in 2000 and 2001 (Fig. 5) is an example of a more detailed analysis of a specific activity. This includes the implementation of RIL techniques during September 2000. Both years, in accordance with the productivity pattern already observed for felling operations, show similar cost trends, characterized by high daily costs at the beginning and end of the harvesting season, and lower daily costs in the middle. Work is often temporarily disturbed by rainfall and technical problems during the beginning and end of the harvest season. The high costs attributed to Team 1 in October 2001, Team 2 in August 2000, and Team 3 in October and November 2000 resulted from technical problems with machines. This highlights the effect of insufficient maintenance. Implementation of RIL contributed to the significantly lower average cost per log in 2001 (Figure 5). Skidding costs decreased by more than US\$7 per log despite the cost for skid trail planning of about US\$0.29/ 
Fig. 5. Costs for skidding a log during the harvest periods 2000 and 2001, affected by the implementation of planned skidding as part of RIL in September 2000.

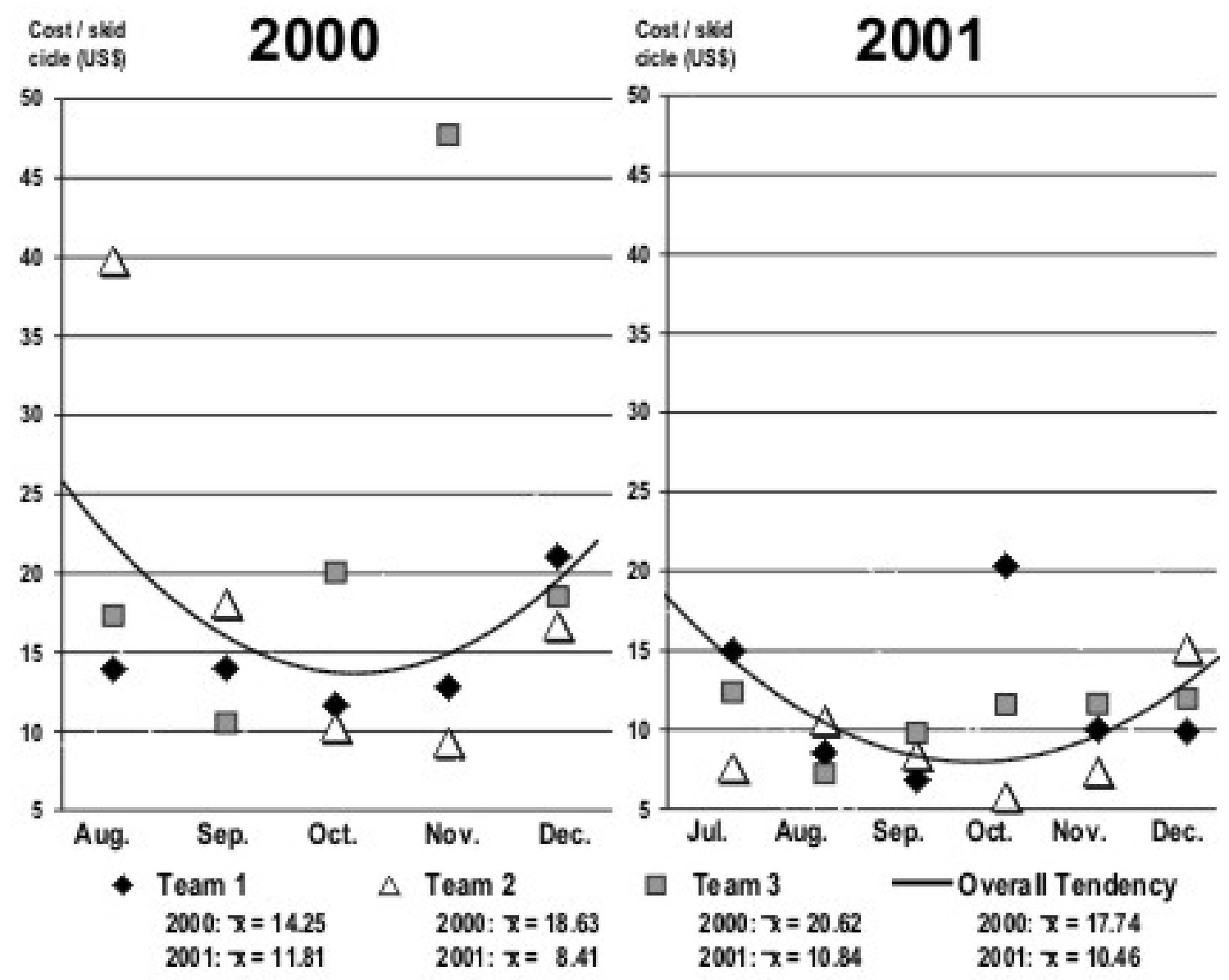

$\mathrm{m}^{3}$. Again, strong differences among the teams were detected. Such insights provide excellent opportunities to enhance operational performance.

\section{DISCUSSION}

We designed the tool for collaborative monitoring of production and costs to be applied by companies in their day-to-day activities to provide them with useful information, and at the same time, to generate reliable data for research. Experience gained during its development, however, revealed some difficulties affecting its more general application:
1. Field reports. Initially, there was considerable apprehension and mistrust on the part of the workforce, but after a few days, all workers completed the daily reports in less than one minute. Nevertheless, continuous supervision and training of newcomers were necessary. The codification system was rapidly assimilated, but lack of awareness and communication often caused serious confusion, when new workers received their numerical codes.

2. Chainsaws. Numbering of chainsaws caused significant problems. They were documented 
correctly in the field reports only after they were permanently marked.

3. Machinery. Estimating fuel and lubricant consumption caused some difficulties when measuring devices were not available at filling points. Training was necessary to ensure accurate estimation of consumption. Documentation of spares was the most difficult task, and their complete documentation was not practical, as there was an incredibly large number of items for each machine, including minor pieces such as screws and lines. It is necessary to have a separate bookkeeping system for spares to provide more general information about the costs for each machine needed for the cost monitoring. Documentation by the operators in the forests was meaningful only for specific items, such as fuel and chains.

4. Database. Use of the database by the company regularly caused problems. As the monitoring tool was developed and tested during the FSC certification process, the company's capacity for data processing was completely absorbed by data generated in inventories, permanent sample plots, and chain of custody required as a matter of priority by the certifiers. Several times, field reports were collected but not processed. This delay interrupted data and communication flow, and often it was not possible to make a timely check of suspect field data or acquire missing information. Also, the lists and codes for employees and machines were not continuously available, and this confused employees and resulted in mistakes in field reports.

5. Bookkeeping system. The bookkeeping system did not allow costs to be kept separately for each machine. It took several attempts before the reluctant administration adapted their bookkeeping routines to resolve this problem.

Most difficulties described above resulted from a lack of clearly defined competencies and data management routines. The employees, already fully occupied with their daily work, perceived the monitoring system as an additional burden, and the enterprise's management concentrated strongly on obligations imposed by the FSC certifier. Discussions with the company management and the staff involved revealed the need for a well-trained information manager to coordinate the various elements of the monitoring system. After significant resistance, the company agreed to employ such a technician, with responsibilities also for other monitoring mechanisms. Experience shows that identification of specific benefits based on the analysis of enterprise-specific data by company personnel will be necessary to convince timber companies to invest in qualified staff and adequate computer equipment. Hence, data should be checked carefully for opportunities to demonstrate benefits of the system, especially in the initial phase of financial monitoring.

\section{CONCLUSIONS}

Existing financial information on natural forest management in the Brazilian Amazon is insufficient for decision making at both company and policy levels. Due to special economic and ecological conditions in the region, forest companies need financial information about their own forest operations to enable informed decisions and efficient use of resources.

Timber companies need external support because they lack the expertise required to capture and analyze financial data; researchers need field data from harvesting operations to evaluate the economic viability of sustainable forest management. To address this problem, a tool for monitoring production and costs of forest operations was developed and tested to facilitate collaboration between companies and researchers. Using this tool, the first long-term documentation of commercial harvest operations in the Amazon showed the competitiveness of RIL for a specific enterprise. The study also confirmed the importance of effective utilization of heavy machinery to partially compensate for lower productivity and additional planning costs when implementing RIL. Due to the ecological and economic heterogeneity of the region, as well as the technical and logistical specifics of the timber enterprises, production and cost data from other Amazonian enterprises are necessary to define more general trends regarding RIL and sustainable forest management.

The tool is simple and provides relevant information for investment decisions, technology selection, 
operational planning, and detection of difficulties and opportunities to improve a company's performance. Successful implementation, however, depends on significant investment in staff and modified administrative procedures, requirements that currently exceed the willingness and capacity of most timber companies in the Amazon.

Generating easily understood and highly relevant results is essential to interest potential clients. It is necessary to have adequate facilities to train technicians as information managers. Training should include basic principles of cost accounting, financial analysis, and investment calculation, as well as communication and information management.

Our experience suggests the tool will be replicable only to highly motivated companies with qualified management staff and an interest in moving from conventional logging toward RIL. It has special relevance for those involved in FSC certification or those who own their own forests or have long-term concessions. Success will also depend on external supervision, especially during the implementation phase. We estimate about one month is needed to get the system working, followed by more extensive support during at least two harvesting seasons.

Successful implementation of the collaborative monitoring approach depends on active support of organizations interested in sustainable forest management, such as certification agencies, development and conservation projects, and governmental organizations responsible for environment and rural development. They must acknowledge that, beyond environmental, technical and social issues, financial aspects are crucial to sustainability. Forest Stewardship Council certifiers, in particular, should include production and cost monitoring as a fundamental prerequisite for certification.

Responses to this article can be read online at: http://www.ecologyandsociety.org/vollo/iss 1/art3/responses/

\section{Acknowledgments:}

This research, a scientific cooperation between the Brazilian Research Organization for Agriculture (EMBRAPA) and the Centre for International Forestry Research (CIFOR), was supported by the
International Tropical Timber Organization (ITTO) through Project Number Project PD 5799 Rev. 2 $(F)$. Additional funding was provided by the Banco daAmazónia(BASA). We would like to acknowledge the gracious support of Idacir Perachi of Juruá Florestal Ltda and all the staff of that company. Special thanks to Dr. Frank Merry from the Woodshole Research Centre and Environmental Research Institute of the Amazon (IPAM) for his constructive contributions, as well as to Dr. Cesar Sabogal, Dr. J. N. M. Silva, and Prof. Dr. Jürgen Bauhus for their valuable comments on the manuscript. Also thanks to Dr. John Turnbull for his review of the paper.

\section{LITERATURE CITED}

Andersen, L. E., C. W. J. Granger, E. J. Reis, D. Weinhold, and S. Wunder. 2002. The dynamics of deforestation and economic development in the Brazilian Amazon. Cambridge University Press, Cambridge, UK.

Arima, E., and A. Veríssimo. 2002. Preços de Madeira em Pólos Madeireiros Próximos de Cinco Florestas Nacionais na Amazônia. Ministério do Meio Ambiente - Programa Nacional de Florestas, Brasília, Brazil.

Barreto P., P. Amaral, E. Vidal, and C. Uhl. 1998. Costs and benefits of forest management for timber production in eastern Amazonia. Forest Ecology and Management 108:9-26.

Barreto, P., and E. Arima. 2002. Florestas Nacionais na Amazônia: Consulta a Empresários e Atores afins à Política Florestal. Ministério do Meio Ambiente, Brasília, Brazil.

Blate, G. M., F. E. Putz, and J. J. C.Zweede. 2001. Progress towards RIL adoption in Brazil and Bolivia: driving forces and implementation successes. Paper presented at the International Conference on 26 February to 1 March 2001, Kuching, Sarawak, Malaysia. FAO, Bangkok, Thailand.

Boltz, F., P. T. Holmes, and D. R. Carter. 2003. Economic and environmental impacts of conventional and reduced-impact logging in tropical South 
America: a comparative review. Forest Policy and Economics 5:69-81.

Costa Filho, P. P., and C. A. P. Ferreira. 1991. Análise comparativa de custo de exploração Florestal mecanizada em Terra Firme. Circular Técnica 63, Embrapa, Belém, Brazil.

Cotton, C., and T. Romine. 1999. Facing destruction. A Greenpeace briefing on the timber industry in the Brazilian Amazon. Greenpeace International Publications, Amsterdam, The Netherlands.

de Graaf N. R., A. M. Filius, and A. R. Huesca Santos. 2002. Financial analysis (of sustained forest management for timber. Perspectives for application of the CELOS management system in Brazilian Amazon. Forest Ecology and Management 177:287-299.

Dillmann D. A. 1978. Telephone and mail surveys: the total design. John Wiley, New York, New York, USA.

Dykstra D. P., and R. Heinrich. 1996. FAO model code of forest harvesting practice. Food and Agriculture Organization, Rome, Italy.

Embrapa. 1996. Diagnóstico dos projetos de manejo florestal no estado do Pará - Fase Paragominas. Report. Embrapa/CPATU, Belém, Brazil.

Enters, T., P. B. Durst, G. B. Applegate, P. C. S. Kho, and G. Man, editors. 2002. Applying reduced impact logging to advance sustainable forest mananagement. Regional Office for Asia and the Pacific (RAP) Publication 2002/14. Asia-Pacific Forestry Commission, Food and Agriculture Organization, RAP, Bangkok, Thailand.

Food and Agriculture Organization of the United Nations (FAO) 1997. Environmentally sound forest harvesting. Testing the applicability of the FAO model code in the Amazon in Brazil. Forest Harvesting Case-Study 8. FAO, Rome, Italy.

Forest Stewardship Council (FSC). 2004. List of certified forests. FSC International Centre, Bonn, Germany. (Online.) URL:

http://www.fsc.org/fsc/whats new/documents/Docs cent/4
Holmes T. P., G. M. Blate, J. C. Zweede, R. Pereira Jr., P. Barreto, F. Boltz, and R. Bauch. 2000. Financial costs and benefits of reduced impact logging relative to conventional logging in the eastern Amazon. Tropical Forest Foundation, Washington, D.C., USA. (Online.) URL:

http://www.srs.fs.usda.gov/econ/pubs/misc/tph001. pdf.

Instituto Brasileiro do Meio Ambiente e dos Recursos Naturais Renováveis (IBAMA). 2002. Comercialização de produtos madereiros da Amazônia 1999-2000. IBAMA, Brasilia, Brazil.

Johns, J., P. Barreto, and C. Uhl. 1996. Logging damage during planned and unplanned logging operations in eastern Amazon. Forest Ecology and Management 89:59-77.

Köppen, W., and R. Geiger. 1954. Klima der Erde. Justus Perthes, Darmstadt, Germany.

Lal P., H. Lim-Applegate, and M. Scoccimarro. 2001. The adaptive decision-making process as a tool for integrated natural resource management: focus, attitudes, and approach. Conservation Ecology 5(2): 11. (Online.) URL:

http://www.consecol.org/vol5/iss2/art11/.

Laurance, W. F., M. A. Cochrane, S. Bergen, P. M. Fearnside, P. Delamônica, C. Barber, S. D'Angelo, and T. Fernandes.2001. The future of the Brazilian Amazon. Science 291:438-439

Lele, U., V. Viana, A. Veríssimo, S. Vosti, K. Perkins, and S. A. Husain. 2000. Brazil: forest in the balance. Challenges of conservation with development. The World Bank Evaluation Country Case Studies. World Bank, Washington, D.C., USA.

Lentini, M., A. Veríssimo, and L. Sobral. 2003. Fatos florestais da Amazônia 2003. Imazon, Belém, Brazil.

Lima, E., A. A. Leite, D. Nepstad, K. Kalif, C. A. Ramos, C. Pereira, A. Alencar, U. Lopes, and F. Merry. 2003. Florestas familiares. Um pacto sócioambiental enre indústria madeireira e a agricultura familiar na Amazônia. Instituto de Pesquisa Ambiental da Amazônia (IPAM), Belém, Brazil.

McDonald, T., and B. Rummer. 2001. Variation in skidder productivity over time during timber 
harvest. In Council of Forest Engineering. Forest engineering challenges: a global perspective. Proceedings of the $25^{\text {th }}$ annual Council on Forest Engineering meeting. 16-20 June 2002, Auburn, Alabama. Corvallis, Oregon, USA. (CD-ROM.)

Ministério do Meio Ambiente (MMA). 2001. Plano nacional florestal. MMA, Brasília, Brazil.

Muehlsiegl, R., and B. Pokorny. 1999. Kostenstruktur eines zertifizierten Forstbetriebes im Amazonasraum am Beispiel von Mil Madeireira in Itacoatiara. Final report. University of Dresden, Dresden, Germany.

Nepstad, D., A. Veríssimo, A. Alencar, C. Nobre, E. Lima, P. Lefebvre, P. Schlesinger, C. Potter, M. A. Cochrane, and V. Brooks. 1999. Large-scale impoverishment of Amazonian forest by logging and fire. Nature 398:505-508.

Nepstad D., A. Veríssimo, P. Moutinho, and C. Nobre. 2000. O empobrecimento oculto da floresta amazônica. Ciência Hoje 157 (27):70-73.

Nepstad, D., C. Azevedo-Ramos, E. Lima, D. McGrath, C. Pereira, and F. Merry. 2004. Managing the Amazon timber industry. Conservation Biology 18 (2):575-577.

Pearce, D, F. Putz, and J. K. Vanclay. 2003. Sustainable forestry in the Tropics: panacea or folly? Forest Ecology and Management 172:229247.

Pokorny, B., and R. Sousa. 2000. Diagnóstico sócio-econômico da indústria madeireira Peracchi no Tailândia, Estado do Pará. Documentos 33. Embrapa Amazônia Oriental, Belém, Brazil.

Rice, R. E., C. A. Sugal, S. M. Ratay, and G. A. B. da Fonseca. 2001. Sustainable forest management. A review of conventional wisdom. Centre for Applied Biodiversity Science. Conservation International, Washington., D.C., USA.

Sabogal, C., J. N. M. Silva, J. Zweede, R. Pereira, Jr., P. Barreto, and C. A. Guerreiro. 2000. Diretrizes técnicas para a exploração de impacto reduzido em operações florestais de terra firme na Amazônia brasileira. Documentos 64. Embrapa, Belém, Brazil.
Sayer, J. A., and B. Campbell. 2001. Research to integrate productivity enhancement, environmental protection, and human development. Conservation Ecology 5(2):32. (Online.) URL:

http://www.consecol.org/vol5/iss2/art32/.

Sayer, J. A., and B. Campbell. 2003. The science of sustainable development. Cambridge University Press, Cambridge, UK.

Scholz, I. 2001. Overexploitation or sustainable management: action patterns of the tropical timber industry: the case of Pará, Brazil, 1960-1997. Frank Cass Publishers, London, UK.

Smeraldi, R., and A. Veríssimo. 1999. Hitting the target. Timber consumption in the Brazilian domestic market and promotion of forest certification. Amigos da Terra, Programa Amazônia, IMAZON, Belém, Brazil.

Smith, W. 2002. The global problem of illegal logging. Tropical Forest Update 12/1:3-5.

Sobral, L., A. Veríssimo, E. Lima, T. Assevedo, and R. Smeraldi. 2002. Acertando o Alvo 2: Consumo de Madeira Amazonica e Certificação no Estado de São Paulo. IMAZON, Belém, Brazil.

Stone, S. W. 1998a. Evolution of the timber industry along an aging frontier; the case of Paragominas (1990-95). World Development 26:433-448.

Stone, S. W. 1998b. Using a geographic information system for applied policy analysis: the case of logging in the Eastern Amazon. Ecological Economics 27:43-61.

Superintendência do Desenvolvimento da Amazônia (SUDAM). 1978. Estudo de viabilidade técnico-econômica da exploração mecanizada em floresta de terra firme na região de Curuá-Una. PNUD/FAO/IBDF BRA-76/027. SUDAM, Belém, Brazil.

United Nations Conference on Environment and Development (UNCED). 1992. Agenda 21: deforestation. Report of the UNCED, 3-14 June 1992, Rio de Janeiro, Brazil. United Nations, New York, New York, USA. (Online.) URL:

http://www.unep.org/Documents/Default.asp? DocumentID=52\&ArticleID=59.

Veríssimo, A., P. Barreto, R. Tarifa, and C. Uhl. 
1992. Logging impacts and prospects for sustainable forest management in an old Amazon frontier: the case of Paragominas. Forest Ecology and Management 55:169-199.

Veríssimo, A., P. Barreto, R. Tarifa and C. Uhl. 1995. Extraction of a high-value natural resource in Amazonia: the case of mahagony. Forest Ecology and Management 72:39-60.

Veríssimo A., M. A. Cochrane, and C. Souza, Jr. 2002. National forests in the Amazon. Science 297:1478.

Vidal, E., V. Viana, and J. L. F. Batista. 2002. Crescimento de floresta tropical três anos após colheita de madeira com e sem manejo florestal na amazônia oriental. Scientia Florestalis 61:133-143.

Wellhoefer, S. 2002. Environmentally sound forest harvesting in Brazil. Assessment of regeneration and environmental impacts four years after harvesting. Forest Harvesting Case Study 19. Food and Agriculture Organization, Rome, Italy. (Online.) URL:

http://www.fao.org/documents/show cdr.asp?url file=/ DOCREP/004/Y4345E/Y4345E00.HTM.

Yin, R. K. 2002. Case study research, design and methods. 3rd ed. Sage Publications, Newbury Park, California, USA. 